\title{
Training and development methods and organizational performance: A case of the local government organization in Central Region, Ghana
}

Godson Kwame Amegayibor

School of Business, University of Cape Coast, Cape Coast, Ghana

godson3005@yahoo.co.uk

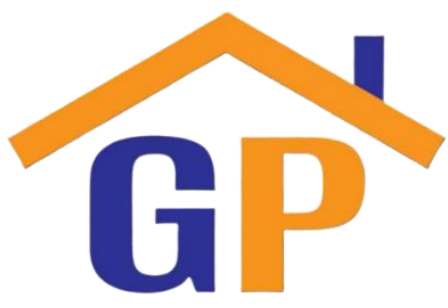

Abstract

Article History

Received on 13 August 2021

$1^{\text {st }}$ Revision on 1 September 2021

$2^{\text {nd }}$ Revision on 9 September 2021

Accepted on 16 September 2021

Purpose: Is to investigate the relationship between training and development (T\&D) methods and organizational performance in the local government sector, as well as contribute to knowledge.

Research Methodology: The study employed a quantitative approach and correlation design, a census sampling method to sample 215 employees, a structured questionnaire to collect data, multiple linear regression to test hypotheses, and the Statistical Package for Social Science (SPSS) version 20 to input, transform and analyze the data.

Result: The result shows that training and development (T \& D) methods (job orientation, job rotation, workshop \& conference, and classroom lectures) had a significant relationship with organizational performance. The findings also revealed that training and development ( $\mathrm{T} \& \mathrm{D})$ methods (job orientation, workshop \& conference, and classroom lectures) have a significant relationship with the quality of service delivery. However, job rotation has no relationship with quality service delivery.

Limitation: The study's main weakness is that it only looked at four different training and development methods and their impact on organizational performance and service quality. Another flaw in the study is that it only looked at one metropolitan assembly.

Contribution: In this regard, metropolitan and municipal assembly executives and managers should consider employing training and development methods that provide stronger predictions to boost the organization's performance and delivery of quality services to communities. They should train and develop employees within the organization as soon as political power changes hands to enhance organization performance because policy adherence is critical to the organization's performance.

Keywords: Training, Development, Local Government Organization, Performance, Organizational Performance

How to cite: Amegayibor, G, K. (2021). Training and development methods and organizational performance: A case of the local government organization in Central Region, Ghana. Journal of Social, Humanity, and Education, 2(1), 35-53.

\section{Introduction}

People are involved in every element of an organization, and their efforts contribute to the organization's success. Employees are an organization's most valuable asset which needs to be trained and developed based on organization and individual needs. As a result of the ever-changing organizational environment, lifelong learning is a vital coping mechanism. Organizational environments vary over time, necessitating ongoing training and development of staff skills and capacities in order to increase work performance, growth, and the ability to adapt quickly to changing 
economic circumstances in order for the institution to remain competitive (Amin, Saeed, \& Lodhi, 2013). Staff training and development are essential in order for them to keep up with current events and practices (Tsaur \& Lin, 2004). Effective training programs, according to Elnaga and Imra (2013), are essential to developing the desired knowledge, skills, and capacities of employees in order for them to perform well on the job. Training and development, according to Abiodun (1999), is the systematic acquisition of knowledge, skills, and attitudes by employees in order for them to perform satisfactorily on a task or job. Training and development is the process of altering an organization's personnel through planned and unplanned learning in order for the institution to gain and sustain a competitive advantage (Harrison, 2000).

Organizations provide training to prepare workers to accomplish their jobs as desired, according to Elnaga and Imra (2013), in order to maximize their employee's potential. It has been observed that most institutions, through long-term planning, invest in developing new skills in their workforce, enabling them to cope with uncertain conditions that they may face in the future, thereby improving employee performance through higher levels of motivation and commitment, and when employees recognize their organization's interest in them through training programs, they are more likely to participate. Training is essential for establishing a flexible, motivated, and devoted team (Amin, Saeed, Lodhi, Mizna, Simra, \& Iqbal, Tehreem, 2013). Recognizing the importance of training and development, the local government sector needs to host training and development programs for its employees on a regular basis. Because the sector is known to have a fairly fluid workforce and is organized as a political institution, the majority of the workforce population is either appointed by the government or voted in by electorates, training and development programs for these staff in the local government sector are extremely important. Because in Ghana each administration is given a fouryear tenure by the 1992 Ghana republican constitution, the majority of these workers are replaced or maintained after that time. As a result, employee training is required for an institution with such a fluid and dynamic workforce, as newly appointed and existing personnel must undergo on-the-job or off-the-job training.

According to Agu (2002), local government training and development in Nigeria are in the deep woods and are plagued by enormous problems. The obvious ramifications of the nation's local government's massive neglect of effective training and development programs are clear. It is critical for the local government sector institutions to provide systematic and adaptable training and career development programs for their personnel. By focusing on specific skills required for the current need, training has been shown to assist employees in their current occupations and help them reach current performance criteria. Too much political appointment of the local governing institutions has been accused of consistent, consequently poor performance in delivering fundamental quality services to communities as a whole.

Yang (2010) believes that the inefficient provision of basic public services by local governments has led to the inefficient supply of basic services to the masses and the deployment of 'fellow citizens' to positions they were not qualifying for within the local government structure. According to Mwesigwa, Bogere, and Anastassova (2021), both elected and appointed officials within these structures may not accurately represent the outcome of the political system. This could be due to the fact that the electorate has few opportunities to interact with their leaders in order to make proposals and receive feedback on policy outcomes. The management and performance of the local governments is thus an issue of both timely and enduring importance to researchers, policy-makers, and citizens alike (Sharpe, 1970). According to Mwesigwa (2021), Ugandan public organizations lack adequate skill in managing community expectations and community pressures in dynamic conditions.

According to Heathfield (2012), providing correct staff training and development at the right time brings significant benefits to the institution and improves performance. Training and development are important factors in defining an organization's optimal performance. It is a good policy for a local government organization to invest in the training and development of employees' skills, knowledge, and abilities to boost individual and, ultimately, organizational performance. Prior studies in the area of training and development (T\&D) and organizational performance focused on sectors such as 
banking (Gunu, Oni, Tsado \& Ajayi, 2013; Oladimeji \& Olanrewaju, 2016; Engetou, 2017; Ojoh \& Okoh, 2015; Falola, Osibanjo \& Ojo, 2014; Emeti, 2015), the oil and gas (Raza, 2015) and Pharmaceutical (Hafeez \& Akbar, 2015). Furthermore, a few Ghanaian researchers have looked at employee performance in industries such as mining (Ali, 2014), banking (Appiah, 2010; Agyei, 2014), security (Okyireh \& Okyireh, 2016), insurance (Hogarh, 2012; Ofobruku \& Nwakoby, 2015), and communication (Tetteh, Sheng, Yong, Narh \& Sackitey, 2017). However, studies on training and development and organizational performance in the local government sector appear to be rare. Furthermore, there appears to be a dearth of literature on the relationship between both training and development methods and organizational performance and quality service delivery in the Ghanaian setting. To address these vacuities, the study looked into the relationship between training and development methods (T\&D) and organizational performance in the local government sector, with the goal of adding to the body of knowledge.

\section{Objectives of the Study}

The following research objectives steer this study:

1. To investigate the relationship between training and development (T\&D) methods organizational performance in the local government sector.

2. To investigate the relationship between training and development (T\&D) methods and quality service delivery in the local government sector.

\section{Literature Review}

\section{Human Capital Theory}

Many studies have demonstrated training and development relates to performance, job satisfaction, service delivery, etc., and is embedded in the human capital theory. The human capital theory which states that training and development have a favorable impact on employee performance, innovation, and career is one of these theories proposed by literature. The theory of human capital is Adam Smith's brain (Schuller \& Field, 1998). In 1961 Schultz further developed this according to literature (Schulz, 1981). It is hypothesized that training, education, and skills investment is an important component in economic growth, physical plant, and equipment investment (Schuller \& Field, 1998). In addition, Bohlander, Snell, and Sherman (2001) describe the meaning of human capital as "knowledge, skills, and capacity of people who value an organization economically." Schultz (1993) described the term "human capital" as an essential factor in the improvement of company assets and staff, both to raise productivity and to maintain competitive advantage. Schultz said it is a tool used for improving productivity to sustain competitiveness in the human capital organization. Boadu, Fokuo- Dwomo, Boakye, and Kwaning (2014) add that investment in training and development thus acts as a catalyst for improved development performance among districts assemblies. Becker (1993) contends, however, that there are different sorts of capitals including education, development, and computer training.

The theory of human capital encourages the provision of education or training to workers that in turn boost their productivity and revenue (Becker, 1964). Some academics (Levin \& Kelley, 1994; Thurow, 1975) have vehemently criticized the theory of human capital that economists and other social scientists have overestimated the payouts from increased training and development as well as overlooked additional contributions to improving productivity, such as training, contracting conditions and management practices. Productivity is mainly a feature of jobs rather than a worker's talent because trained workers are easier to train. However, the human capital theory has proven durable and remains the basic theoretical structure used to understand investment in human capital, from a personal and company standpoint (Bassi \& McMurrer, 2006). The theory was significant to this study, because human capital is a primary driving component in an organization's activities, and must be trained and developed to achieve excellent performances and accomplish organizational goals. The theory is well-known in the literature as one of the best theories for determining the influence or degree of effect independent variables and their resulting factor-dependent variables. 


\section{Concepts of Training and Development}

Training and development is a dynamic, flexible, and complicated concept with no universally accepted definition (Cloete \& Mokgoro, 1995). This has provided researchers and scholars with the opportunity to conceptualize training and development in relation to the type of organization under investigation or the study area.

\section{Training}

Training is the process of inspiring new or current personnel, especially in public and political service, with knowledge and expertise to fulfill their organizational objectives based on public policy direction. Cheminais, Bayat, van der Waldt, and Fox (1998) define training as "planned and purposeful activities that improve knowledge, skills, insight, attitude, behavior, values, and working and thinking habits of public servants or prospective public servants in order for them to perform designated or intended tasks more efficiently." Training is defined as the systematic development of skills, standards, concepts, and attitudes leading to better work performance (Goldstein, 1993). Employee training also involves systematic planning and behavioral changes through instructional events, programs, and instructions that help people to get the necessary information, expertise, and skills to operate successfully (Armstrong, 2006). Buckley and Caple (2000) describe training as an endeavor to change or build information, skills, or attitudes through the learning experience, in order to attain an efficient performance in a particular activity or set of activities.

\section{Development}

Development is the act of increasing and gaining the information needed to carry out specific tasks or responsibilities in a position. According to Tailor (2000), development is the process of broadening people's options and increasing their level of well-being. It is a comprehensive, integrated process in which economic and political forces interact in dynamic and diverse ways to improve the lives and opportunities of the poorest people. Development is the continuation of education and training in order to gain the necessary experience, skills, and attitude to be appointed to the highest positions (Cheminais, Bayat, van der Waldt, \& Fox, 1998). Only by development, did individuals or groups acquire knowledge, abilities, values, and conduct as a learning experience of every sort. It is more professional than job-oriented, with an emphasis on the individual's long-term development and potential. Employee development can be demonstrated in a variety of ways, according to Katcher and Snyder (2003), including training, evaluation, education, and even feedback received from communities they serve.

\section{Difference Between Training and Development}

Although in most kinds of literature there have been no evident differences between training and development, some other scholars have devoted efforts to address these gaps. The difference between training and development, according to Olusoji, Adedayo, and Akaighe (2017), training provides new employees with the learning procedure, in which they learn the key skills needed to get the job done while developing the training process to enhance their skills by the existing employees. Training is a short-term capacity enhancement procedure that takes from 3 to 6 months. Development is a continuous process that is typically carried out over the long term, and the focus for training is on skills and knowledge development for present jobs. Training of employees is an essential aspect of human capital production (Tzafrir, 2005). Training is specially intended to ensure that the employee continues to provide the greatest results in a favorable way. The training focuses on identifying, ensuring, and enabling individuals to carry out their existing employment through planned learning and core competencies (Buckley \& Caple, 2000). Employees trained for personal and organizational purposes become more efficient. Training effects on employee performance often promote growth in the employee and the organization (Katcher \& Snyder, 2003).

\section{Methods of Training and Development}

Kibibi (2011) has split training and development into 2 primary groups, namely on-the-job and offthe-job. Ojoh and Okoh (2016) emphasized that two main types of training normally exist, namely on and off the job. But Lisk (1996) identifies macro and micro training and development. Both on-thejob and off-the-job training, according to Amoah-Mensah and Darkwa (2016), are genre terms for 
training and development classifications rather than training and development approaches per se. That an organization can choose to train its employees on the job or off the job; on-the-job training takes place inside (internally) the organization, whilst off-the-job training takes place outside (externally). This study posits that the research training and development, as previously said, differs based on the sort of company providing the training. The type of training and development methodologies to be employed to suit the needs of the organization and its personnel would be determined by the needs of the individual and organization.

\section{Off-the-Job Training}

Formal training may also include daytime training type, which allows employees to attend formal lectures one or two working days off weekly or monthly (Ojoh \& Okoh, 2016; Ali, 2014). This sort of training takes place outside of the workplace, according to Ojoh and Okoh, however, attempts in some cases to stimulate the actual working environment are made, while training outside the workplace can be focused on the classroom with seminars, lectures, and movies. They may involve training in the vestibular, where an employee works on the actual equipment and materials, but in a room other than that in which he works. The reasons are to minimize the pressure at work that could limit learning. The method enables the employment of a wider range of training activities, including apprenticeships, lectures, assistantships, internships, special studies, films, televised conferences or discussions, case studies, role acting, simulation programmed instruction, and laboratory training (Cole, 2002).

\section{Job Orientation}

Is the introduction of new employees into their existing position by teaching them the skills and knowledge needed in their present position or position. The orientation of the newly selected personnel soon after they have been employed is provided. The new employees also have to use the orientation method to enable them to build confidence and perform better in order to reach their chosen expectations. The times may vary depending on the situation, from a few days to a few weeks (Ali, 2014). Milkovich and Boudreau (2004) view guidance as an ongoing process, taking time to achieve it. Based on three factors, organizations are guiding their new employees. In the first place, the orientation will allow the new employee to learn about work practices. The new employee is also oriented to the relationship with other employees. In the end, it makes the new employee think that he or she is a member of the organization. Kumar and Siddika (2017) said it is another approach to training and development. This comprises familiarizing and training new employees with the new role in an organization. In this procedure, they are exposed to the nature of their new employment. A successful orientation gives employees different benefits and as an institution as a whole (Richards, 2017). Orientation is the key aspect to cut sales and hence to reduce costs in order to run your firm (Klein \& Weaver, 2000).

\section{Job Rotation}

The rotation of work is based on the knowledge, skills, and skillful capability of an individual, according to Jorgensen, Davis, Kotowski, Aedla, and Dunning (2005). This is about training new employees, enabling them to get to know the work and the entire business as far as values, rules, and regulations are concerned (Olaniyan \& Ojo, 2008). Tuei and Saina (2015) make this progress by moving the learner from one lateral task to another, which allows the employee to gain skills. That the rotation of the task makes the trainee a multi-skilled worker and increases the performance. This strategy is excellent to increase the experience of an individual in organizing activities and turn a professional into general practitioners, develop their personal know-how, enable employees to gain new information, and encourage fresh ideas (Ali, 2014). Tuei and Saina (2015) advance that job rotation is when the trainee moves from one task lateral to another which affords the employee the opportunity to acquire skills. Job rotation enables the trainee to become a multi-skilled employee.

\section{On-the-job training}

According to Ojoh and Okoh (2016), these two sorts of training take place when the supervisor or senior officer takes time out of his or her schedule to coach or instruct his or her subordinate. It could take the form of job rotation, in which employees are allowed to move from one unit or department to another, working on a succession of jobs and gaining a variety of abilities. Job rotation is especially 
common in service businesses such as banks and insurance companies. Kibibi (2011) states that onthe-job techniques are procedures that are used in the workplace while employees are working to learn specific skills. This strategy is essential to improve the understanding of personnel who have insufficient academic qualifications for job performance. It is also viewed as training within the context of the organization's policy. The firm trains employees using four main techniques: orientation, job instruction, job rotation, and coaching (Ali, 2014; Laing, 2009). On-the-job training could be a continuous procedure that does not significantly impede routine business operations.

\section{Classroom Lecture}

Is an official technique for employees to gain the skills and knowledge essential to carry out future work or tasks and is conducted externally to employees and it mainly takes place in a classroom in which specialists and academics can have an impact on knowledge and experience based on research. Sutherland (1976) remarked that a lecture is about the process by which a trainer teaches or orally disseminates information or ideas to trainees who have little or no engagement. The knowledge can come from his own lectures, investigations, and experiences. According to Ahammad (2013), this approach is used to teach many people a great deal of knowledge and if the subject is comprehensive. Ojoh and Okoh (2015) stressed that the training circumstances are traditionally controlled by the trainer. Efficiency can be assessed by the goal or by knowledge and its development is inexpensive and time and group size versatile in application. The speech, however, will not alter the position and will make little contribution to capacity building. Certain lectures may be boring, others without instruction can be humorous.

\section{Conferences and Workshop}

This sort of training is generally done within one week or two outside of the working environment, which allows employees to learn from experts, professionals, and consultants. On the occasion of the conference, Saakshi (2005) indicated that it is a strategy utilized to help employees improve problems. This is an informational and working sequence in which small groups of individuals meet in a short space of time to discuss a particular area of concern. The workshops are kinds of training in which skills are gained externally to the organization and trainees are taken away from their working environments. That immediately in the workstation can be handy. In this manner, the trainer lectures on the specific subject and answers questions and discussions. The leader of the conference must have the skills needed to guide the debate significantly without losing sight of the subject or subject (Kibibi, 2011). This form of training and development is characterized as an approach involving presentations to a large audience by more than one person. It is more affordable because a group of employees is instructed simultaneously in huge audiences on a certain topic. However, these methods are bad because it isn't easy for every individual trainee to understand the subject as a whole because not all trainees follow the same speed during the training sessions and focus on particular trainees who appear to be understanding the subject faster than others so that other people are trained (Kumar \& Siddika, 2017).

\section{Training and Development Process}

A variety of training literature (Cuming, 1980, Hanif, 2013, Benedicta, 2010) has traditionally indicated that training involves the organization's systematic approach, generally following a series of training policies that are supported by the identification of training needs, the design of training, and the evaluation and feedback training programs. The training and development process implies the procedures or stages by which the objectives of personnel and organizational needs that enable the organization to attain the desired objectives are addressed. The training and development process involves four phases or stages according to Desmone, Werner, and Harris (2002). These include training needs assessment, training design, training execution, monitoring, and training assessment. This is done in a sequential manner in order to achieve the desired result.

\section{Training and Development Needs Assessment}

The training requirement is defined by Cole (2002) as any lack of knowledge, understanding, and attitude on behalf of the employee in relation to the job or expectations for corporate change. Barbazette (2006) believes that the process of collecting information to educate personnel to meet 
organizational demands is an assessment of training needs. In order to conduct the education and development process, Onah (2008) indicated that it is necessary, inside an organization, to analyze the need for four information, therefore data of organization-level (management, product/services communication channel offered and personnel requirements) (i.e. occupational standards agreed nationally for different levels of responsibility). However, Noe (2013) points out that the assessment of training needs concerns the process of finding out whether or not training is required. Three tests are conducted: staff (personnel), organizational, and work (job) tests. The training needs analysis emphasized by Armstrong (2003) is likewise divided into three phases: firstly, the total corporate need organization, the team in second departments, the tasks or occupation of the organizing needs group, and thirdly, the individual needs of employees. McConnell (2003) argues that an examination of training needs is necessary when changes are made to a system/work, new technologies are introduced, new standards are implemented, work or performance quality declines, skills and knowledge are lacking and incentives are lacking.

\section{Design of the Training and Development}

Details of the training program such as trainer identity, methodology, skill, material, etc. are defined in this stage. Training and development design, according to Noe (2013), has to do with the components or activities included in the training program to maximize the likelihood of a high degree of knowledge transfer. Training design focuses on the definition and identification of goals and scope, methods and media to follow. The design of training and development should include the opinions of management, supervisors, and employees and full participation in them (Brown \& Harvey, 2000). Zaccarelli (1997) explains the training process as follows: participants, trainers, methodologies and procedures to be employed, training level, and venue should also be discussed. This training plan will provide guidance to the trainer and trainee in order to carry out the program successfully. It includes those who participate in the training, the person who administers the program, the resources necessary, and the content to be followed. The training lesson is developed once the plan for the program has been determined.

\section{Implementation of Training and Development}

Training and development implementation mostly involves implementing the plan or design. The implementation of training and development is the start of the training and development program, according to Hailemichael (2014). The organization's reporting and readiness to deliver and learn respectively by trainers and trainees. The program, as agreed, should also start on time. Resources are offered and are ready for use such as money, automobiles, instructional aides, and learning materials. Equipment such as classrooms, equipment, lighting systems, physical surroundings, and the overall environment should also be learning-friendly. This means that each organization must be planned, implemented systematically, and adapted to enhance performance and productivity in order to achieve the objectives of its training program (Armstrong, 2008).

\section{Monitoring, Evaluation of Training and Development}

Evaluation and monitoring are processes used to measure the training and development program efficacy and efficiency. Evaluation is therefore the means of measuring a training program's effectiveness. Assessment is vital to determine whether the training program is effective or not and whether its objectives are accomplished. This is a crucial stage that not only evaluates the quality of training provided but also the training plan to see whether future revisions would improve it in terms of results. Training assessment may take a number of forms, including questioning, observation, questionnaires, test effect, etc., according to Beardwell and Holden (1993). This is designed to have a longer-term and broader impact. It provides the response as to how much the training was kept and used after a period of time by the trainee at the workplace. The duration may be many weeks, months or even longer. Evaluation promotes training by feedback for trainers, members, and employers and evaluates the competence level of employees (Pynes 2004). Training programs can be evaluated at four main levels, according to Kirkpatrick and Kirkpatrick (2006). The first stage is to measure the reactions of participants to the training programme. To this step, Kirkpatrick and Kirkpatrick refers to the satisfaction of customers. The second level assesses the occurrence of learning as a result of the training. Have the participants gained the skills or information that are part of the goals? The third 
level of assessment assesses the extent to which the participants who attended the training program are affected by behavioral change on the job. The use of performance assessments aiming to gauge the new competencies is another strategy with this level of assessment. The fourth level tries to measure the ultimate results achieved when staff participated in the training. Training is ideally associated with the performance of employees. At this level, the assessment aims to assess the effect of the training on the organization. Satisfactory end-points may involve fewer supervisor complaints, higher staff productivity, reduced client complaints, a reduction in job accidents, higher funding amounts, better board relationships, and fewer discriminatory workplace situations. A final stage is to examine whether the training benefits outweigh their direct and indirect expenses.

\section{Local Government Organization}

In Ghana, local government organizations are known as Metropolitan, Municipal, and District Assemblies (MMDAs). They are supported by Ghana's Republican Constitution of 1992. The Constitution states unequivocally in Chapter 20, Article 240 (1), that "Ghana shall have a system of local government and administration that shall, as far as practicable, be decentralized." There are several departments that implement decisions made by the general assembly of each local government. Accounting, auditing, planning, and engineering are just a few of the functions performed by officials in this decentralized organization (Crawford, 2004). Local government organizations provide important services to citizens and must live up to the public's expectations by providing high-quality, efficient services (Buccus, Hemson, Hicks \& Piper, 2007). The goal is to improve people's quality of life by providing essential quality services and creating an enabling environment to ensure the organization's growth. Stakeholders, civil society organizations, and individuals demand accountability and openness from local government institutions that receive taxpayer funds, with an emphasis on efficiency (Brusca \& Montesinos, 2016). The argument that public sector organizations frequently have numerous goals, as a result of which they are connected with many dimensions of performance, has received a lot of attention in the literature (Boyne 2010, Halligan, Bouckaert, \& Dooren, 2010).

\section{Performance}

Performance denotes progress toward goal achievement and is intended to strengthen municipalities' abilities to be more responsive, effective, and sensitive to constituent demands, while also being efficient in utilizing the limited available resources to address those demands (Putman 1993; Turk, 2016). Performance refers to how well it achieves its policy objective or other intended effects. Performance signifies effectiveness (equity, empathy, ecology), efficiency, economics, and ethics in public administration (Doherty \& Horne, 2002). It is also argued that in order to define organizational performance, conceptual frameworks of performance must be properly specified so that all essential stakeholders can agree on what performance comprises (Dess \& Robinson, 1984).

\section{Organizational Performance}

The definition of organizational effectiveness or performance is a contentious issue (Mitchell, 2012). This is always conceptualized from the perspective of the researcher, the research area, the organizational perspective, and other scholars in the field of study. Organizational performance is commonly defined as the extent to which a corporation achieves its goals (Miles, 1980, Price, 1972). The organizational performance was used to determine the extent to which organizations considering social systems met their goals (Georgopoulos \& Tannenbaum, 1957). Organizational performance is concerned with the extent to which public and private agencies are able to carry out their core mandates by carrying out appropriate administrative and operational functions in ways that seek to achieve both short and long-term objectives (Kim, 2005). Organizational performance is frequently a feature of internal control systems that involve periodic evaluation of performance standards and how operational objectives are met (Kloot \& Martin, 2000). Organizational performance is defined by Boyne (2003) as the 3Es: economy, efficiency, and effectiveness of public services. The cost of procuring specific service inputs (facilities, staff, and equipment) for a given quality is referred to as the economy. Efficiency is defined as the technical cost per unit of output, as well as the responsiveness of services to public preferences, which results in measures of user satisfaction 
(Jackson, 1982). The actual achievement of institutional service objectives is referred to as effectiveness (Boyne, 2002).

\section{Empirical Review and Hypotheses}

The impact of training and development on organizational performance was researched by Khan, Khan, and Khan (2011). Using a sample size of 100, questionnaires, and descriptive statistics, the study indicated that Training and Development has a favorable effect on Organizational Performance. A case study of select banks in Nigeria (Gunu, Oni, Tsado \& Ajayi, 2013) examines training and development relationships as an instrument for organizational performance. On the basis of survey design, questionnaires, and Pearson moment correlations, descriptive statistics. The study has shown a beneficial association between training and development and banks' performance in Nigeria. Training and development: is it important in providing quality service at Sinapi Aba Trust, Kumasi? Ampong, Nkuah and Okyere (2020) following interviews and questionnaires, the samples were 60 and nonexperimental study designs it was found that training and development enhance employee performance and has a good impact on the SAT delivery system. Altarawneh (2005) explores Jordanian banking organizations' existing practices, policies, and training and development roles (T\&D). The study demonstrates that in the majority of the businesses, there is a lack of a systematic assessment of the needs of employees and an effective assessment process. The multi-method approach was adopted with a purposeful sample of 15 senior managers and $38 \mathrm{HRM}$ management. T\&D enhances the skills, knowledge, attitudes, and behaviour, but doesn't raise the commitment and satisfaction of employees. T\&D does not affect the organizations in profit, innovation and change, sales, absenteeism, turnover, job satisfaction, and cost savings, but promotes customer satisfaction, quality service, and productivity. The study by Mpofu and Hlatywayo (2015) examined the association between staff quality training and development and service delivery in a selected township. The questionnaire, 150-sample employees, and the ANOVA had been employed for analysis in the quantitative approach. The results showed the necessity for efficient training and development methods and processes for employees to obtain better employee results, improving the provision in the communities of fundamental services. Gupta (2017) investigated the relationship between training, development, and organizational performance (The Case of Commercial Bank of Ethiopia). The stratified, simple random sampling of 125 staff, questionnaires, descriptive and inferential analyses, based on a sectional and quantitative approach. The study concluded that training and development influence the performance of the organization. Based on the above it is hypothesized that:

H1: Training and Development $(T \& D)$ methods influence organizational performance.

H2: Training and Development ( $T \& D)$ methods influence quality service delivery.

\section{Conceptual Framework}

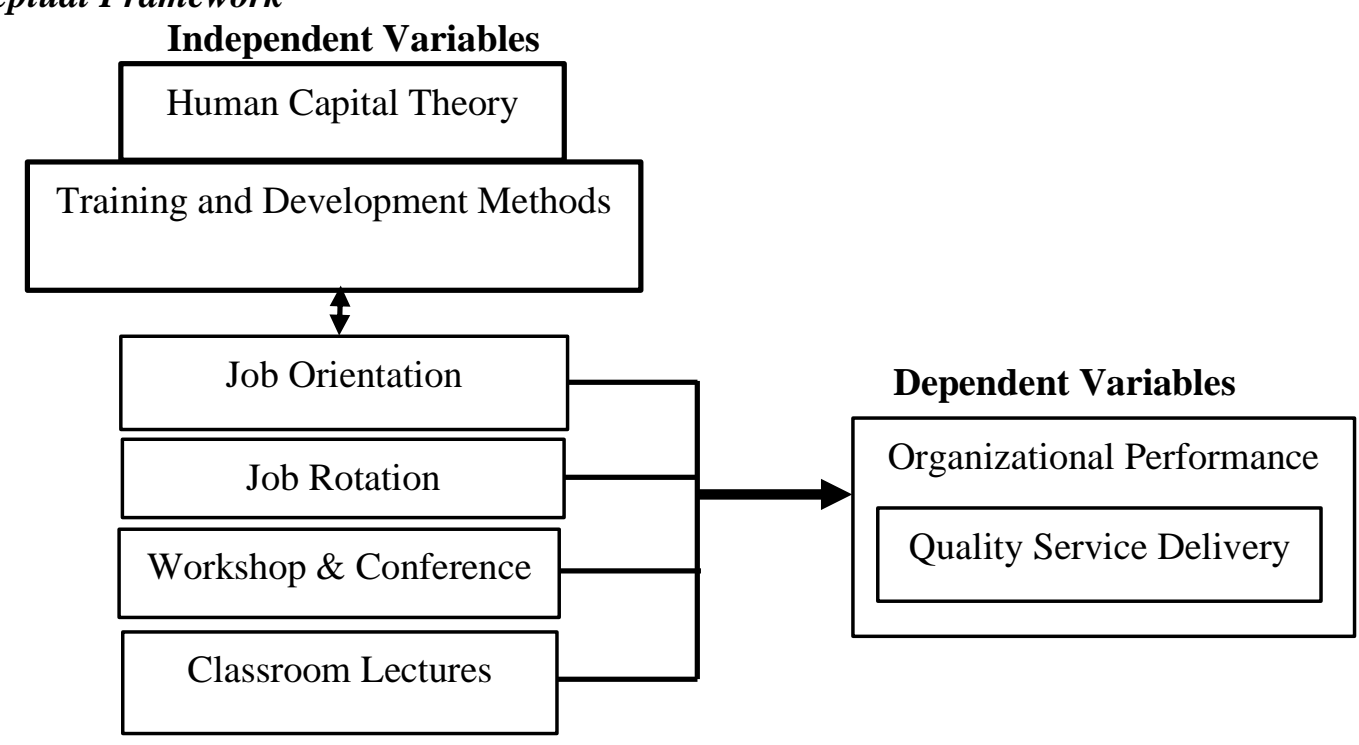


This study's conceptual framework is based and anchored on the theory of human capital. Education, training, and development theory teaches workers useful information and skills, which in turn boost their productivity, service delivery, and incomes. Human capital is the transfer of training to the welfare of an organization and staff in order to carry out its work successfully. The theory indicates that training and development methods (therefore job orientation, job rotation, workshop \& conference, and classroom lectures) are hypothesized to influence organizational performance and quality service delivery, as demonstrated in the framework.

\section{Research Methodology Research Design}

The study took place at Cape Coast Metropolitan Assembly with thirteen (13) departments. They are central administration, internal audit, finance/revenue, social welfare/community dev, urban roads, budget, transport, legal, waste management/environment, public works, environmental health, planning, and procurement \& stores. The population for the study comprised 215 employees, of 13 departments of Cape Coast Metropolitan Assembly. These thirteen departments have been places where work processes in regards to delivering the objectives of the organization occur. The population includes employees of the Cape Coast Metropolitan Assembly and the entire population has been used for this study. The quantitative research approach was employed to allow the researcher to achieve objective and reasonable findings. The quantitative method allows researchers to employ mathematical approaches to achieve objective and logical deductions (Creswell, 2009). Creswell (2014) further states that the approach of quantitative research is utilized to examine objective ideas by investigating the inter-variable relationships. The variables can, in turn, be measured on instruments in order to examine numerated data using statistical processes. The design of descriptive quantitative correlation studies was used as both Creswell (2008) and Lappe (2000) claim that quantitative correlative study results are anticipated and relations between variables may be explained. There were 215 people in the survey from 13 departments. The method of census sampling was used. Prasad (2015) stressed the census approach to ensure a high level of precision and practical phenomenon description with no element of bias since all the factors have no probability of being taken into account. Census is one way to use the complete population as a sample, according to Singh and Masuku (2014). A census is more appealing for small populations, despite the fact that financial considerations make it impracticable for big populations. A census removes sampling error and provides information on all members of the population. In addition, some costs such as questionnaire design and developing the sampling frame are "fixed,". To attain a desired level of precision, the complete population will have to be sampled in small groups.

\section{Data Collection and Analysis}

Structured questionnaires were used as a research instrument since it is a reasonable method for the collection of data from a possible required number of respondents. According to Abawi (2017), it is appropriate for quantitative data collection because it allows for subjective and objective data collection as well as participant privacy protection. The survey instrument was divided into three parts A, B, and C. Section 1(A) deals with the personal data (demographics), such as gender, education, department, and experience of the personnel. The second part (B) covers training and development methods that are job orientation, rotation of job, Workshops \& Conferences, and classroom lectures. Section 3 (C) also dealt with organizational performance and service delivery. The independent variables training and development $(T \& D)$ were rated on a five-point Likert scale, with 1 indicating least satisfied, 2 indicating less satisfied, 3 indicating satisfied, 4 indicating much satisfied, and 5 indicating most satisfied. Organizational performance and service delivery were also evaluated on a five-point Likert scale, with 1 denoting little influence, 2 denoting less influence, 3 denoting influence, 4 denoting much influence, and 5 denoting the most influence. It is vital to use Likert-type scales and to allow the researcher to calculate Cronbach's internal consistency alpha coefficient (Gay, Mills, \& Airasian, 2006). Instructors in the area reviewed the structured questionnaire for face and content validity, and their feedback was included in the final instrument before administration. The instrument was also examined for internal consistency dependability using the Cronbach Alpha 
reliability index, and the results revealed 0.75 , indicating that the instrument was trustworthy enough to produce reliable and valid data. The data collection took two months and involved 215 questionnaires. The two hypotheses were tested using a multiple linear regression test. The Statistical Social Science Package (SPSS) 20.0 version was used for data entry, data transformation, outputs, and analysis.

\section{Organizational Performance Measures}

Every organization must have a performance measurement system because such a system is critical in developing strategic plans and evaluating the success of organizational objectives (Ittner \& Larcker, 1998). According to Armstrong (2006) and Hakala (2008), various authors in the field of business and human resource management suggest quality, customer satisfaction, timelessness, absenteeism/tardiness, and achievement of goals as indicators of organizational performance. However, in the perspective of Matei and Elis-Bianca (2013), the results of the local government and public sector were measured in a wide variety of ways. Such as efficient services, equity, nondiscriminatory treatment, diversity in management, respect for the right, democracy, fairness, and dignity. Organizations in the public sector use performance management and measurement systems to improve the efficiency and effectiveness of service delivery (Wouter, Bouckaert, \& Halligan, 2015). Some organizations in the public sector, such as those in the health and education sectors, use performance measurement systems. Local government organizations, on the other hand, are notorious for opposing the use of performance measurement systems, which research has shown to improve organizations' efficiency, effectiveness, and outcomes (Holzer, Fry, Charbonneau, Van, Wang, \& Burnash, 2009). This implies that organizational performance measures are determined by the organization and its stakeholders in order to achieve the organization's target or goals.

\section{Results and Discussion}

\section{Descriptive Statistic}

Analysis of Demographic Variables

Table 1:

Respondents' Demographic Information $(N=215)$

\begin{tabular}{llll}
\hline Items & & Frequency & Percent \\
\hline Gender & Male & 126 & 58 \\
Education & Female & 89 & 42 \\
& Secondary & 13 & 6 \\
& Technical & 19 & 9 \\
Diploma & 51 & 24 \\
Bachelors & 100 & 46 \\
Department & Post-graduate & 33 & 15 \\
& Central Administration & 70 & 33 \\
& Internal Audit & 16 & 7 \\
& Finance/Revenue & 8 & 3 \\
& Social welfare/Community & 9 & 4 \\
& Dev. & & \\
& Urban Roads & 6 & 1 \\
& Budget & 2 & 4 \\
Transport & 9 & 1 \\
& Legal & 2 & 9 \\
& Waste management/ Env. & 19 & 12 \\
& Public works & 25 & 16 \\
Experience & Environmental Health & 34 & 5 \\
& Planning & 11 & 2 \\
& Procurement /Stores & 4 & 17 \\
& Less than a year & 36 & 25 \\
& 1-5 years & 55 & 30 \\
\hline
\end{tabular}




$\begin{array}{lll}11 \text { years and above } & 60 & 28 \\ 18-30 \text { years } & 100 & 47 \\ 31-40 \text { years } & 50 & 23 \\ 41-50 \text { years } & 45 & 21 \\ 51-\text { above year } & 20 & 9\end{array}$

Table 1 shows that of 215 respondents, 126 of them are male, representing 58 percent, 89 of them, 42 percent are female. 13 participants who were 6 percent had secondary school education, 19 representing 9 percent were technically educated, 51 were diploma graduates representing 24 percent, 100 respondents representing 46 percent were bachelor's holders, 33 were postgraduate students representing 15 percent. 70 respondents representing 33 percent were in the central administration, 16 respondents representing 7 percent were in internal audit, 8 respondents representing 3 percent were in finance/revenue, 9 respondents represented 4 percent in social welfare/community development, 6 respondents representing 3 percent worked on urban roads, 2 respondents representing 1 percent worked on the budget, 9 respondents representing 4 percent worked in the transport, 2 respondents representing 1 percent worked on the legal, 19 respondents representing 9 percent were in waste management and environmental, 25 respondents representing 12 percent were in public works, 34 respondents representing 16 percent were in environmental health, 11 respondents representing 5 percent in the area of planning and 4 respondents representing 2 percent working in procurement departments correspondingly. The table further indicated that 36 of 17 percent were in the establishment for fewer than one year, 55 of them 25 percent worked for 1-5 years, 65 of them worked for 30 percent from 6 to 10 years and 60 of them worked 11 years and older. The table again showed that 100 respondents between the ages of 18 and 30 years represented 47 percent, 50 respondents between the ages of 31 and 40 years represented 23 percent, 45 respondents between the ages of 41 and 50 years represented 21 percent, and 20 respondents between the ages of 51 and above years represented 9 percent. This shows that male respondents outnumber female respondents in the company. Central administration had the most responders, followed by public works and trash collection. The firm employed the greatest number of people with 6 to 10 years of experience. Bachelor's and post-graduate - replies predominate in terms of educational degree.

\section{Hypotheses Testing}

Multiple Linear Regression Analysis

The regression analysis has been conducted in order to determine the statistical significance between the independent variables Training and development methods (job guidance, job rotation, workshop and conference and lectures in the classroom) and dependent organization's performance in the local government sector.

H1: Training and Development ( $\&$ D) methods influence organizational performance.

\section{Table 2:}

Association between Training and Development Methods and Organizational Performance.

\begin{tabular}{lcccc}
\hline Predictors & Std. Error & $\begin{array}{c}\text { Std Coefficients } \\
\operatorname{Beta}(\beta)\end{array}$ & $\mathbf{T}$ & $\mathbf{P}-$ Value
\end{tabular}

(Constant)

.230

4.527

.000

Training and Development Methods:

$\begin{array}{lcccc}\text { Job Orientation } & .043 & .260 & 4.002 & .000 \\ \text { Job Rotation } & .041 & .153 & 2.532 & .012 \\ \text { hop \& Conference } & .056 & .210 & 2.937 & .004 \\ \text { Classroom lecture } & .056 & .286 & 3.824 & .000\end{array}$

R Square $=.581 ;$ Adjusted R Square $=.566 ;$ P-value $=0.00$ 
Table 2 shows that the independent variables training and development methods job orientation $(\beta=.260, P .000)$, job rotation $(\beta=.153, P=.012)$, workshop \& conference $(\beta=.210, P=.004)$, and classroom lecture $(\beta=.286, \mathrm{P}=.000)$ all had a significant association with the dependent variable organizational performance. Based on that, hypotheses $\mathrm{H} 1$ was supported, which states that Training and Development ( $\mathrm{T} \& \mathrm{D}$ ) methods influences organizational performance, because the $\mathrm{p}$ - value for job orientation, job rotation, workshop \& conference, and classroom lecture was smaller than the alpha $(\alpha)$ value of 0.05 .

H2: Training and Development ( $\&$ D) methods influence quality service delivery.

\section{Table 3:}

Association between Training and Development Methods and Quality Service Delivery.

\begin{tabular}{lcccc}
\hline Predictors & Std. Error & $\begin{array}{c}\text { Std Coefficients } \\
\text { Beta }(\beta)\end{array}$ & T & P - Value
\end{tabular}

(Constant)

.317

4.943

.000

\section{Training and Development Methods:}

\begin{tabular}{lcccc} 
Job Orientation & .059 & .389 & 5.140 & .000 \\
Job Rotation & .057 & -.010 & -.142 & .887 \\
hop \& Conference & .076 & .192 & 2.287 & .024 \\
Classroom lecture & .077 & .236 & 2.671 & .008 \\
\hline
\end{tabular}

\section{R Square $=.431 ;$ Adjusted R Square $=.410 ;$ P-value $=\mathbf{0 . 0 0}$}

Table 3 demonstrates that the independent variables training and development approaches job orientation $(\beta=.389, \mathrm{P}=.000)$, workshop and conference $(\beta=.192, \mathrm{P}=.024)$, and classroom lecture $(\beta=.236, \mathrm{P}=.008)$ all showed a significant relationship with the dependent variable quality service delivery. Hypothesis H1 was validated as a result, which asserts that Training and Development (T \& D) approaches influence quality service delivery, because the $\mathrm{p}$ - value for job orientation, workshop $\&$ conference, and classroom lecture was less than the alpha $(\alpha)$ value of 0.05 . However, one independent variable $(\beta=-.010, P=.887)$ shows no significant link with quality service delivery and was not supported because the $p-$ value was bigger than the alpha $(\alpha)$ value of 0.05 .

\section{Discussion}

The purpose of this research was to investigate the relationship between training and development ( $\mathrm{T}$ \& D) methods and organizational performance in the local government sector. Two hypotheses were formulated based on two objectives that support the study. Statistical data show that H1 is supported, indicating that training and development ( $\mathrm{T} \& \mathrm{D})$ methods (job orientation, job rotation, workshop \& conference, and classroom lecture) have an effect on organizational performance and that training and development methods are strongly related to organizational performance. Furthermore, the data have shown that training and development methods (job orientation, workshops, and conferences, classrooms lectures) have an influence on quality service delivery and $\mathrm{H} 2$ has been supported. This means that improvement in these strategies will improve organizational performance and quality service delivery. However, there are no relationships between the training and development (T\&D) method (job rotation) and quality service delivery and improvement in this method will not improve the quality of services in the local government sector. Previous empirical investigations indicate that training and development strategies have an impact on organizational performance. This study's findings support the conclusions of (Khan, Khan, \& Khan, 2011), (Gunu, Oni, Tsado, \& Ajayi, 2013), and (Gupta, 2017) that training and development approach influence organizational performance. The findings also support (Ampong, Nkuah, \& Okyere, 2020), (Altarawneh, 2005), and (Mpofu \& Hlatywayo, 2015) that training and development techniques influence quality service delivery. In a smooth, politically active organization, to ensure effectiveness and efficiency. Emphasis needs to be placed on work orientation, workshops/ conferences, and lectures in the classroom. More attention 
should also be paid to job orientation, workshop/conference, and classroom lectures, and fewer job rotations in order to attain extremely high-quality services to communities as a whole.

\section{Conclusion}

Previous research has underlined the importance of training and development (T\&D) methods and employee and organizational performance in other sectors such as banking, oil and gas, agriculture, and so on, but research on T\&D in the local government sector appears to be scarce. As a result, it is vital to investigate and establish any issue pertaining to training and development methods as well as organizational performance in the local government sector. The objective of this research is to investigate the relationship between the training and development (T\&D) methods and the organizational performance in the local government sector in the Central Region of Ghana. The sample was drawn from the Cape Coast Metropolitan Assembly in Ghana's Central Region. The study concludes that training and development (T\&D) methods (job orientation, job rotation, workshop \& conference, and classroom) had a significant relationship with organizational performance. Training and development (T\&D) methods (job orientation, workshop \& conference, and classroom) had a significant relationship with quality service delivery.

\section{Implication}

This study's findings have theoretical and practical implications. The hypothesis demonstrates that when training and development are performed with the proper investment objectives and are not politically motivated, they will improve employee, organizational performance, and quality service delivery. To improve organizational performance and quality service delivery at Metropolitan Assembly, there is room to improve training and development approaches as well as the delivery process. Its management should guarantee that there is sufficient employee engagement in T\&D initiatives through improved content and delivery processes to improve organizational performance, as the majority of the organization's personnel are political appointments and only a few are nonpolitical appointments. Specific content and delivery mechanisms should be developed for different levels of employees to ensure their readiness to take on tasks and accept change. The management of the organization should guarantee that significant employee participation in T\&D methods initiatives is achieved by improving content and delivery processes to enhance organizational effectiveness, since most employees are political and only limited, because in a politically charged climate like the study area where the winner takes all, policy direction and service delivery may be delayed.

\section{Limitation and Study Forward}

For academic research, defining the study's constraints is crucial. As a result, before proceeding, it is critical to acknowledge the current study's limitations. To begin, one of the study's key shortcomings is that it only examined four alternative training and development methods. Another limitation of the study is that it only looked at how training and development improve organizational performance and quality service delivery in one metropolitan assembly. Only a few studies on the effects of training and development on organizational performance and none on the local government sector have been conducted.

\section{Acknowledgment}

For their professional supervision, advice, encouragement, and good intentions I would like to thank my supervisors, Dr. Aborampah Amoah-Mensah of Studies Management and Ms. Edina Okoley of the Ministry of Human Resource Management. I'm grateful beyond words. Dr. Dei Mensah is also praised for her important contribution to refining this work. The constant support of Mr. Elliot Nyieku is recognized again throughout my lifetime. Finally, my thanks go to my friends and family, particularly to my father and mother, and to my sister, Emelia Amegayibor, to my wife Abigail Sadzo; and to the children Nukunu, Nuna and Zebulon, and Gordon for the inspiration and financial support they provided during this research. I would like to express my gratitude to all my family and my friends for their support. 


\section{References}

Abawi, K. (2017). Data Collection methods (Questionnaire \& Interview). Training in Sexual and Reproductive Health Research, Geneva Workshop. URL: https://www.gfmer.ch/SRH-Course2017/Geneva-Workshop/pdf/Data-collection-methods-Abawi-2017.pdf.

Abiodun, E.J.A. (1999). Human Resources management, an overview. Concept Publication, Shomolu, Lagos. P. 110-121.

Agu, S.U. (2002). Local government training programmes: Practical problems and pragmatic solutions in human resource management the local government system in Nigeria, Nsukka: AP Express Publishers.

Agyei, M. D. (2014). The impact of training and development programmes on the performance of employees in rural banks in the Ashanti Region. (Master's Thesis), Kwame Nkrumah University of Science and Technology, School of Business, Knust College of Art and Social Sciences, Kumasi, Ghana.

Ahammad, S. (2013). Importance of training in the hotel industry: A case study of Hilton Hotel, Cyprus, (Master's thesis), Sodertorns University, School of Business Studies, Sodertorns, Cyprus.

Ali, J. (2014). Assessing the effect of training and development on employee performance at Anglogold Ashanti, Obuasi Mine (Doctoral dissertation), Kumasi, Ghana.

Altarawneh, I. (2005). Training and development effectiveness: practices, roles and impacts on performance in Jordanian banking organizations (Ph.D. Thesis). University of Huddersfield, UK.

Amin, A., Saeed, R. M., \& Lodhi, R. N. (2013). The Impact of Employees Training On the Job Performance in Education Sector of Pakistan. Middle-East Journal of Scientific Research, 17(9), 1273-1278.

Amin, A. R. Saeed, R. N. Lodhi; Mizna, Simra, A. Iqbal D. R. Tehreem. E. (2013). The impact of employees training on the job performance in education sector of Pakistan. Middle-East Journal of Scientific Research. 17 (9), 1273-1278.

Amoah-Mensah, A. \& Darkwa, P. (2016). Training and development process and employees' performance in the "Chop bar" industry. Journal of Research and Development (JRnD), 3(1).

Ampong I, Nkuah J.K. Okyere E. (2020). Training and development: Does it matter in quality service delivery at Sinapi Aba", American International Journal of Business Management (AIJBM Journal), 1(1), 1-27.

Appiah, B. (2010). Impact of training on employee performance: a case study of HFC bank (Ghana) limited. Unpublished project work, Ashesi University College. Accra, Ghana.

Armstrong, M. (2008). Strategic human resource management, a guide to action, London: Kogan Page.

Armstrong, M. (2006). A handbook on personnel management practice, (10th ed.). London: Kogan Page.

Armstrong, M. (2003). A handbook of human resources management (8th ed.). London: Kogan Page.

Barbazette, J. (2006). Training needs assessment: Methods, tools and techniques. San Francisco: Pfeiffer.

Bassi, L.J \& McMurrer, D.P (2006) Employers' perspectives on human capital development and management. Organization for Economic Co-operation and Development (OECD).

Beardwell, N. \& Holden, B. (1993). Managing for success, (2nd ed.). England: Prentice Hall.

Becker, G.S. (1993). Human capital: A theoretical and empirical analysis with special reference to education (3rd ed.). Chicago: University of Chicago Press.

Becker, G. (1964). Human capital. Columbia University Press. New York.

Benedicta, A. (2010). The impact of training on employee performance: A case study of HFC bank (Ghana) Ltd. (A Research Project) Ashei University College, Accra, Ghana.

Boadu, F., Fokuo- Dwomo, E., Boakye J. K. \& Kwaning, C. O. (2014). Training and development: a tool for employee performance in the District Assemblies in Ghana, International Journal of Education and Research, 2 (5), 513-522.

Bohlander, G., Snell, S. \& Sherman, A. (2001). Managing human resources. Mason: South- Western College Publishing. 
Boyne, G. A. (2010). Strategic planning, public service improvement: Theories and evidence. Oxford: Oxford University Press.

Boyne, G. A. (2003). Sources of public service improvement. A critical review and research agenda. Journal of Public Administration Research and Theory, 13(3), 367-394.

Boyne, George A. (2002). Public and private management: What's the difference? Journal of Management Studies, 39(1), 97-129.

Brown, R. \& Harvey, D. (2000). Human resource management experiential approach. California. California State University Press.

Brusca, I. \& Montesinos, L. (2016). Implementing performance reporting in local government: A cross-countries comparison, Public Performance \& Management Review (39), 506-34.

Buccus, I., Hemson, D., Hicks, J. \& Piper, L. (2007). Public Participation and Local Governance. Research report prepared by the Centre for Public Participation in association with the HSRC and University of KwaZulu-Natal. KawaZullu-Natal: Centre for Public Participation in Association with the HSRC and University of KwaZulu-Natal.

Buckley, R. and Caple, J. (2000). The theory and practice of training, (4th ed.). Kogan Page Ltd.

Cheminais, J., Van der Waldt, G. \& Bayat, S. (1998). The provision and maintenance of public personnel. Kenwyn: Juta.

Cloete, F. \& Mokgoro, J. (1995). Policies for public service transformation. Cape Town: Juta

Cole, G. A. (2002). Personnel and human resource management, (5th ed.). Continuum London: New York Publishers.

Crawford, G. (2004). Democratic decentralization in Ghana: Issues and prospects. POLIS Working Paper, 9.

Creswell, J. W. (2014). Research design: Qualitative, quantitative and mixed methods approaches (4th ed.). Thousand Oaks, CA: Sage.

Creswell, J. W. (2009). Research Design: Qualitative, Quantitative, and Mixed Methods Approaches (3rd ed). Los Angeles: Sage Publications Inc.

Creswell, J. W. (2008). Educational research: Planning, conducting, and evaluating quantitative and qualitative research. Upper Saddle River, NJ: Pearson/Merrill Education.

Cuming, M. W. (1980). The theory and practice of personnel management. 4th Edition London Butler and Taller Ltd. Pg: 320.

Desimone, R. L., Werner, J. M., and Harris, D.M. (2002). Human Resource Development (3rd ed). Orlando: Harcourt College Publishers.

Dess, G. G. \& Robinson, J. R. B. (1984). Measuring organizational performance in the absence of objective measures: The case of the privately-held firm and conglomerate business unit, Strategic Management Journal 5(3), 265-273.

Doherty, T., \& Horne, T. (2002). Managing public services, implementing changes a thoughtful approach. Published by Routledge, 343-344

Elnaga, A., \& Imran, A. (2013). The effect of training on employee performance. European Journal of Business Management, 5(4), 137-147.

Emeti, C.I. (2011). Human resource management practices and organizational performance in paint manufacturing Firms in Rivers State, (Unpublished PhD Thesis), Abakaliki, Ebonyi State University, Nigeria.

Engetou, E. (2017). The impact of training and development on organizational performance. Case study: National financial credit bank Kumba. Unpublished master's thesis, Central University of Applied Sciences.

Falola, H.O., Osibanjo, A.O \& Ojo, S.I. (2014). Effectiveness of training and development on employees' performance and organization competitiveness in the Nigerian banking industry. Bulletin of the Transilvania University of Braşov Series V: Economic Sciences, 7 (56), 162170.

Gay, L. R., Mills, G. E., \& Airasian, P. (2009). Educational research: Competencies for analysis and applications. Columbus, $\mathrm{OH}$ : Merrill.

Georgopoulos, B.S. \& Tannenbaum, A.S. (1957). A study of organizational effectiveness. American Sociological Review, 534- 540.

Goldstein, I. L., Ford, K. (2002). Training in organizations: needs assessment, development and evaluation (4th Edn.). Belmont. Wadsworth. 
Gunu, U., Oni, E., Tsado, E. \& Ajayi, O. (2013). Empirical study of training and development as a tool for organizational performance: case study of selected banks in Nigeria. Kuwait Chapter of Arabian Journal of Business and Management Review 2, (10).

Gupta, M. (2017). Corporate social responsibility, employee-company identification, and organizational commitment. Mediation by employee engagement. Curr. Psychol. 36, 101109. doi: 10.1007/s12144-015-9389-8.

Hafeez, U., \& Akbar, W. (2015). Impact of training on employees' performance, (Evidence from pharmaceutical companies in Karachi, Pakistan). Business Management and Strategy, 6(1), 49-64.

Hailemichael, K. (2014). The challenges of human resource training and development: The case of Mekelle polytechnic college. (Master of Arts, Thesis), University of Addisa Ababa. Addisa Ababa.

Hakala, D. (2008). 16 Ways to Measure Employee Performance. HR World, http://www.hrworld.com/features/16, ways-measure-performance-021908, [accessed 14 June, 2021].

Halligan, J., Bouckaert, G. \& Dooren, W. V. (2010). Performance Management in the Public Sector: Routledge.

Hanif, F. (2013). Impact of training on employee's development and performance in hotel industry of Lahore, Pakistan. Journal of Business Studies Quarterly, 4(4).

Harrison, R. (2000). Employee development, Beejman Publishing, Silver Lakes, Pretoria.

Heathfield, S. M. (2012). Training: Your investment on people development and retention. About.com Guide. Human Resource (on-line) Assessed on January 20, 2012 from the World Wide Web. http://humanresources.about.com/od/educationgeneral/a/training invest.htm.

Hogarh, J. K. (2012). The effect of training on staff performance: A case study of sic insurance company limited (Master's Thesis), Kwame Nkrumah University of Science and Technology, Kumasi, Ghana.

Holzer, M., Fry, J., Charbonneau, E., Van R. G., Wang, T. \& Burnash, E. (2009). Literature review and analysis related to optimal municipal size and efficiency. Austin: Newark, School of Public Affairs and Administration.

Ittner, C.D. \& Larcker, D.F. (1998). Are non-financial measures leading indicators of future financial performance? An analysis of customer satisfaction, Journal of Accounting Research, 36, 1-35.

Jackson, P. (1982). The political economy of bureaucracy. Oxford: Phillip Allen

Jorgensen, M., Davis, K., Kotowski, S., Aedla, P., \& Dunning, K. (2005). Characteristics of Job Rotation in the Midwest US Manufacturing Sector. Ergonomics, 48.

Khan, R.A.G., Khan, F.A. \& Khan, M.A. (2011). Impact of training and development on organizational performance. Global Journal of Management and Business Research, 11(7), 62,68 .

Katcher, S. \& Snyder, T. (2003). Organizational commitment. USA: Atomic Dog.

Kibibi, M. H. (2011). The impact of training and development on the performance of administrative staff in the public sector organization: The case of second vice presidents' office - Zanzibar. Unpublished master's dissertation Open university of Tanzania, Tanzania.

Kim, S. (2005). Individual-level factors and organizational performance in government organizations, Journal of Public Administration Research and Theory, 15(2), 245-261.

Kirkpatrick, D. L., \& Kirkpatrick, J. D. (2006). Evaluating training programs: The four levels (3rd ed.). San Francisco, CA: Berrett-Koehler Publishers.

Klein, H. J., \& Weaver, N. A. (2000). The effectiveness of an organizational-level orientation training program in the socialization of new hires. Personnel Psychology, 53(1), 47-66.

Kloot, L., \& Martin, J. (2000). Strategic performance management: a balanced approach to performance management issues in local government. Management Accounting Research. 11, 231- 251.

Kumar, D., \& Siddika, H. (2017). Benefits of training and development program on employee's performance: A study with special reference to banking sector in Bangladesh. International Journal of Research Granthaalayah, 5, 77-88. doi:10.5281/zenodo.1133603 
Laing, I. F. (2009). The impact of training and development on worker performance and productivity in public sector organization: a case study of Ghana ports and harbor authority. (Unpublished master's thesis), Kwame Nkrumah University Science and Technology, Kumasi, Ghana.

Lappe, J. (2000). Taking the mystery out of research: descriptive correlational design. Orthopedic Nursing, 19 (2), 1-81.

Levin, H. M. and Kelley, C. (1994). Can education do it along? Economics of Education Review 13 (2), 97-108.

Lisk, F. (1996). Human resources development for management and development. The courier, 159, 5355.

Matei, A. \& Elis-Bianca, E. (2013). Good local public administration and performance: An empirical study, Procedia - Social and Behavioral Sciences, 81, 449 - 453.

McConnell, J.H. (2003). How to identify your organization's training needs: A practical guide to needs analysis, New York: AMACOM.

Miles, R. H. (1980). Macro organizational behavior. Santa Monica, CA: Goodyear Pub. Co.

Milkovick, G.T. \& Boudreau, J.W. (2004). Personnel, human resource management: A diagnostic approach (5th ed.). Delhi: Business Publications Inc.

Mitchell, G.E., (2012). The construct of organizational effectiveness: Perspectives from leaders of international nonprofits in the United States. Nonprofit and Voluntary Sector Quarterly,42(2), 324-345.

Mpofu, M., \& Hlatwayo, C. K. (2015). Training and development as a tool for improving basic service delivery: The case of a selected municipality. Journal of Economics, Finance and Administrative Science, 20, 133-136.

Mwesigwa, D., Bogere, M., \& Anastassova, L. (2021). Integrated policy formulation processes in local governments: A case study in mid-western Uganda. Journal of Governance and Accountability Studies,1(2), 83-101.

Mwesigwa, D. (2021). Public service delivery in Uganda: a reconsideration of grand corruption. Dynamics of Politics and Democracy, 1(1), 1-13.

Noe, R.A. 2013. Employee training and development (6th ed.). New York: McGraw-Hill.

Ofobruku, S. A. \& Nwakoby, N. P. (2015). Effect of training on employees' productivity in Nigeria insurance industry, British Journal of Economics, Management \& Trade, 7(3), 227-235.

Ojoh, J. \& Okoh, L. (2015). The impact of training on employees' job performance: an empirical study of selected organizations in Warri, Delta, State. Journal of Policy and Development Studies (9), 3.

Okyireh, R. \& Okyireh, M. (2016). Experience of social media, training and development on work proficiency: a qualitative study with security personnel: Journal of Education and Practice, 7 (30).

Oladimeji M.A., \& Olanrewaju, T.L. (2016). Empirical evaluation of effect of training \& staff development on organization performance of Islamic financial institutions in Nigeria. Business and Management Research Journal, 6(10), 109 - 117.

Olaniyan, D. A., \& Ojo, L. B. (2008). Staff training and development: A vital tool for organisational effectiveness: The European Journal of Scientific, 24(3), 326-331. Retrieved from http://www.eurojournal.com/ejsr.htm

Olusoji, G., Adedayo M. A. \& Akaighe, G. (2017). Effect of manpower training and development on organisational goals attainment: a study of lapo microfinance bank limited, Lagos, JORIND 15(1).

Onah, F. O. (2008). Human Resource Management (2th Edition). Enugu: John Jacob's Classic Publishers Ltd.

Prasad, V. R. (2015). A note on sampling method, AE International Journal of Multidisciplinary Research, AEIJMR, 3(1).

Price, J. L. (1972). The study of organizational effectiveness, Sociological Quarterly, 13(1): 3- 15

Putnam, R. D. (1993). Making democracy work. Princeton: Princeton University Press.

Pynes, J. E. (2004). The implementation of workforce and succession planning in the public sector. Public Personnel Management, 33(4), 389-404.

Raza, I. (2015). Impact of training and development on employee performance. European Journal of Business and Management, 5 (28). 
Richards, J. C. (2017). Teaching english through english: Proficiency, pedagogy and performance. RELC Journal, 48(1), 7-30. https://doi.org/10.1177/0033688217690059.

Tailor, V. (2000). Report for South Africa: Transformation for human development. Pretoria.

Tetteh, S., Sheng, W. C., Yong, L. D., Narh, O. C., \& Sackitey, O. E. (2017). The impact of training and development on employee' performance (a case study of Millicom Ghana Limited Tigo). International Journal of Information Research and Review, 4(1), 3482-348.

Thurow. L. (1975). Generating inequality. Basic Books, Inc, New York

Tsaur, S.H., Lin, Y.C. (2004). Promoting service quality in tourist hotels: the role of HRM practices and service behaviour, Tourism Management, 25(5), 471- 481.

Tuei, A.C. \& Saina, P.C. (2015). Job rotation: An examination of its effect on employee performance at KCB branches in the North Rift region, Kenya. International Journal of Advanced Research in Management and Social Sciences, 4(5), 84-93.

Turk, K. (2016). Performance management of academic staff and its effectiveness to teaching and researchbased on the example of Estonian universities. TRAMES, 2016, 20 (70),1, 17-36.

Tzafrir, S. S. (2005). The relationship between trust, HRM practices and firm performance, International Journal of Human Resource Management, 16(9), 1600-1622.

Saakshi, N.C.J. (2005). Personnel Management and Human Resources, (1st ed.), New Delhi. A.I.T.B.S. Publisher.

Schuller, T. \& Field, J. (1998). Social capital, human capital and the learning society. International Journal of Lifelong Education, 17 (4), 226-235.

Schultz, T.W. (1993). The economic importance of human capital in modernization, Education Economics, 1(1), 13-19.

Schultz, T. W. (1981). Investing in people, the economics of population quarterly, Berkley: University of California Press.

Sharpe, L.P. (1970). Theories and values of local government, Political Science Studies, (18), 153 174.

Singh, A. S., \& Masuku, M. B. (2014). Sampling techniques \& determination of sample size in applied statistics research: An overview. International Journal of Economics, Commerce and Management, 2(11), 1-22.

Sutherland, T.M. (1976). The lecture method. NACTA Journal, 20(3), 29-32.

Wouter, V. D., Bouckaert, G., \& Halligan, J. (2015). Performance management in the public sector. London: Routledge.

Yang, X. (2010). The importance of staff training in the hotel industry, Vaasan University of Applied Sciences. Vaasan Ammattikorkeakoulu.

Zaccarelli, H. E. (1997). Improving employee performance: effective training strategies and techniques. London: Kogan. 